\title{
Metabolic response of Antarctic pteropods (Mollusca: Gastropoda) to food deprivation and regional productivity
}

\author{
Amy E. Maas ${ }^{1, *}$, Leanne E. Elder ${ }^{1}$, Heidi M. Dierssen ${ }^{2}$, Brad A. Seibel ${ }^{1}$ \\ ${ }^{1}$ Department of Biological Sciences, University of Rhode Island, Kingston, Rhode Island 02881, USA \\ ${ }^{2}$ Department of Marine Sciences, University of Connecticut, Groton, Connecticut 06340, USA
}

\begin{abstract}
Pteropods are an abundant group of pelagic gastropods that, although temporally and spatially patchy in the Southern Ocean, can play an important role in food webs and biochemical cycles. We found that the metabolic rate in Limacina helicina antarctica is depressed $(\sim 23 \%)$ at lower mean chlorophyll a ( $\mathrm{chl}$ a) concentrations in the Ross Sea. To assess the specific impact of food deprivation on these animals, we quantified aerobic respiration and ammonia $\left(\mathrm{NH}_{3}\right)$ production for 2 dominant Antarctic pteropods, L. helicina antarctica and Clione limacina antarctica. Pteropods collected from sites west of Ross Island, Antarctica were held in captivity for a period of 1 to $13 \mathrm{~d}$ to determine their metabolic response to laboratory-induced food deprivation. L. helicina antarctica reduced oxygen consumption by $\sim 20 \%$ after 4 d in captivity. Ammonia excretion was not significantly affected, suggesting a greater reliance on protein as a substrate for cellular respiration during starvation. The oxygen consumption rate of the gymnosome, C. limacina antarctica, was reduced by $\sim 35 \%$ and $\mathrm{NH}_{3}$ excretion by $\sim 55 \%$ after $4 \mathrm{~d}$ without prey. Our results indicate that there is a link between the large scale chl a concentrations of the Ross Sea and the baseline metabolic rate of pteropods which impacts these animals across multiple seasons.
\end{abstract}

KEY WORDS: Pteropod $\cdot$ Zooplankton $\cdot$ Antarctica $\cdot$ Metabolism $\cdot$ Feeding $\cdot$ Temperature

\section{INTRODUCTION}

Limacina helicina antarctica (hereafter Limacina) is a thecosomatous (shelled) pteropod that is often a major component of the planktonic community in the Ross Sea (Hopkins 1987, Hunt et al. 2008, Ross et al. 2008, Elliott et al. 2009). These omnivorous pelagic gastropods use mucus webs and ciliary action to entrain large quantities of phytoplankton, efficiently ingesting $\sim 2000$ to $6000 \mathrm{ng}$ of pigment ind. ${ }^{-1} \mathrm{~d}^{-1}$ (Pakhomov et al. 2002). The unique mucus webs of thecosome pteropods allow them to trap particles from $2 \mu \mathrm{m}$ to $\sim 1 \mathrm{~mm}$, a size range which enables them to feed on diatoms as well as both the unicellular and colonial aggregates of Phaeocystis antarctica ice algae (Hopkins 1987, Gilmer \& Harbison 1991). In regions where their populations are dense, their grazing results in a substantial flux of biogenic carbon from surface waters as strings of mucus-bound discarded particles ('pseudo-feces', Gilmer \& Harbison 1986), remnants of mucus webs, and waste pellets, sink to depth. Accornero et al. (2003) found that, during certain seasons, Limacina fecal pellets were responsible for $95.5 \%$ of the mass flux in the Ross Sea. Further research suggested that pteropods could contribute up to $72 \%$ of the Ross Sea organic carbon export during bloom periods (Manno et al. 2010).

Due to their aragonite shells, thecosomatous pteropods are also responsible for a large portion of calcium carbonate $\left(\mathrm{CaCO}_{3}\right)$ flux in polar waters. These shells have been documented to contribute substan- 
tially to the carbonate flux south of the Polar Front (Collier et al. 2000, Honjo et al. 2000, Honjo 2004). However, the pteropod contribution to the biogeochemical carbon cycling in Antarctic waters is still not well understood, in part due to the variability in pteropod population density, lack of knowledge about life cycles, lack of direct measurements of dissolution and sinking rates and an incomplete understanding of metabolic rates (Hunt et al. 2008). This dearth of information about pteropods has become notable as the growing concerns about ocean acidification have highlighted the potential susceptibility of marine calcifiers in polar regions (Seibel \& Fabry 2003, Orr et al. 2005, Fabry et al. 2008).

Aside from being prominent primary consumers of phytoplankton and important contributors to the organic carbon and $\mathrm{CaCO}_{3}$ cycles in the Ross Sea, thecosomes are prey for seabirds, whales, fish, and crustaceans (Lalli \& Gilmer 1989, Foster \& Montgomery 1993, Hunt et al. 2008). Limacina is also the exclusive food for the gymnosomatous pteropod Clione limacina antarctica (hereafter Clione) (Gilmer \& Lalli 1990). All gymnosome pteropods studied to date are feeding specialists on thecosomes, consuming the soft bodies of their prey and discarding the empty $\mathrm{CaCO}_{3}$ shells. This has led to an evolutionary arms race between the families, which links the behavior, morphology, and physiology of each predator-prey pair (Seibel et al. 2007). Very little is known about the place of Clione in the Southern Ocean food web. It is little reported from the guts of Antarctic organisms, perhaps due to its novel antifeedant compound, pteroenone, which has been shown to deter a number of fishes from feeding on it (Bryan et al. 1995). Little to no research has assessed how the biology or feeding habits of Clione might affect the biogeochemical processes in this region. However, the particularities of its diet result in an extremely high assimilation efficiency and an unambiguous source of prey (Conover \& Lalli 1974), which make it a good model for investigating trophic dynamics.

Production (growth and reproduction) in the Southern Ocean is generally limited by food availability rather than temperature (Clarke 1988). Phytoplankton levels in polar seas have been linked to in situ growth rates of Antarctic krill Euphausia superba both within and between seasons, with krill populations responding to changing phytoplankton populations within a week or less (Ross et al. 2000). The ability to respond to fluctuating food levels in a short period of time allows polar organisms to take advantage of the highly sporadic availability of food. The increase in growth rate during periods of food avail- ability is linked with a rise in metabolic rate, referred to as the specific dynamic action (SDA). SDA is a result of the energy required to mechanically process the food and the biochemical cost of processing and assimilating the nutrients (for review see Secor 2009). As a result of lower basal metabolic rates in frigid waters, the SDA of polar marine ectotherms often results in a lower absolute increase in oxygen consumption, but it has been shown that the effect lasts for a longer period of time (Peck \& Veal 2001). The extended duration of SDA in these species impacts longer term patterns of production in Antarctic species.

There has been much speculation as to how global climate change will affect the already highly variable assemblages of phytoplankton in the Southern Ocean, with uncertain implications for the carbon budget and living biomass production (Sarmiento et al. 1998, Arrigo et al. 1999, Moline et al. 2008). Irrespective of whether phytoplankton mass increases or decreases, we need a clear understanding of how changing productivity directly impacts important primary and secondary consumer zooplankton species. This study presents laboratory experiments which compare the oxygen consumption and ammonia excretion during the first 1 to $3 \mathrm{~d}$ of food deprivation to the next 4 to $13 \mathrm{~d}$ in Clione and Limacina. These measurements inform our analysis of the metabolic rate measurements for the 2 dominant pteropod species in the Ross Sea, Antarctica, over 5 separate seasons. Our data extends previous observations made by Seibel \& Dierssen (2003) to an unprecedented 5 yr time series that illuminates an important relationship between metabolism and regional productivity.

\section{METHODS}

\section{Collection}

Ross Island is located just off the coast of the Antarctic continent in the Ross Sea, south of New Zealand. Here, at McMurdo Station and in the northern ice-free shorelines, we caught pteropods for our study during January and February of 2007 and 2008 (Fig. 1). At Barne Beach, Cape Bird, Cape Royds, and Cape Evans, organisms were hand captured using $500 \mathrm{ml}$ beakers attached to long handles, sometimes referred to as 'jelly dippers'. The pteropods were carefully placed in plastic bottles filled with ambient seawater, packed in coolers and returned to the laboratory at McMurdo station. There we immediately transferred the pteropods into a room refrigerated to 


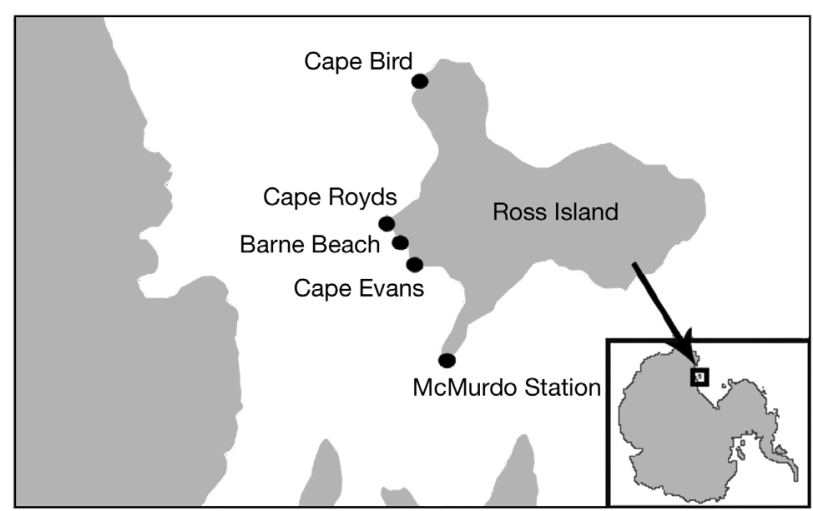

Fig. 1. Sampling sites on Ross Island $\left(\sim 162^{\circ}\right.$ to $171^{\circ} \mathrm{E}, \sim 77^{\circ}$ to $78^{\circ} \mathrm{S}$ ). Pteropods were collected with jelly dippers from all coastal ice-free sites and returned to the laboratory at McMurdo Station

$-2^{\circ} \mathrm{C}$ and moved them into $0.2 \mu \mathrm{m}$ filtered seawater in 11 nalgene bottles. Limacina were kept at densities of $\leq 15$ ind. $\mathrm{l}^{-1}$, Clione at densities of $\leq 10$ ind. $\mathrm{l}^{-1}$. Animals were held for $<48 \mathrm{~h}$ during inter-annual and temperature experiments and up to $13 \mathrm{~d}$ for the food deprivation study. Water was changed daily for all experiments. Methods for specimen collection from 1999, 2001 and 2002 are as described in Seibel \& Dierssen (2003).

\section{Metabolic rate}

After a period of 1 to $13 \mathrm{~d}$, Clione individuals were removed from the refrigerated room and placed in $50 \mathrm{ml}$ airtight glass syringes, which served as respiration chambers. These animals were incubated in a water bath at either $+2^{\circ}$ or $-2^{\circ} \mathrm{C}$. A control syringe containing no organism was set up for every 1 to 2 experimental syringes and was allowed to incubate simultaneously. After 20 to $28 \mathrm{~h}$ we drew water samples from the respiration chamber using a Hamilton gas tight syringe $(500 \mu \mathrm{l})$ and injected them through a Clarke-type oxygen electrode (Strathkelvin Instruments) in a water-jacketed injection port (Marsh \& Manahan 1999). The electrodes were calibrated using air- and nitrogen-saturated seawater maintained at the experimental temperature. The oxygen content in all experiments never dropped below $70 \%$ saturation, a level well above the oxygen partial pressure critical for marine mollusks (Childress \& Seibel 1998).

Aliquots of water were retrieved and analyzed for ammonia concentration using the indophenol blue colorimetric assay (Ivancic \& Degobbis 1984). Each Clione was blotted dry and weighed on an analytical balance before being frozen in liquid nitrogen. Studies of Limacina were conducted using the same methodology, except that individuals were incubated in $10 \mathrm{ml}$ syringes because of their smaller mass. To accurately weigh these organisms, water was gently blotted from the aperture and the outside of the shell. The amount of oxygen consumed and nitrogen excreted was determined by calculating the difference between control and experimental concentrations and incorporating the adjusted volume of water, wet mass of the organism, and time elapsed.

Metabolic rate $(\mathrm{Y})$ was related to wet mass (M) according to the power regression $\mathrm{Y}=a \mathrm{M}^{b}$, where $a$ is a normalization constant and $b$ is the scaling coefficient. These coefficients were then used to compare the oxygen consumption rates $(\mathrm{R})$ of specimens over their normothermic range $\left(T=+2\right.$ to $\left.-2^{\circ} \mathrm{C}\right)$ resulting in a temperature coefficient $\left(Q_{10}\right)$, where $Q_{10}=$ $\left(\mathrm{R}_{2} / \mathrm{R}_{1}\right)^{[(T 2-T 1) / 10]}$. To avoid interannual variations due to differences in mass and physiological state, temperature coefficients were calculated using rates from specimens collected within a single year (2008).

\section{Mass and protein content}

Upon completion of metabolic experiments, frozen specimens were transported to the University of Rhode Island and reweighed on a Cahn Microbalance (ATI Cahn E2000D). Protein levels were quantified spectrophotometrically using a Bicinchoninic Acid Kit for protein determination (Sigma-Aldrich, BCA1). To measure dry mass, specimens were dried in an oven at $60^{\circ} \mathrm{C}$. To ensure full desiccation, samples were dried for $24 \mathrm{~h}$, weighed, and then returned to the oven for a further $4 \mathrm{~h}$. These samples did not change in mass, indicating that a constant weight had been attained after $24 \mathrm{~h}$. All subsequent samples were dried for $24 \mathrm{~h}$. Ash free dry mass was determined by combusting dried specimens in a muffle furnace at $450^{\circ} \mathrm{C}$ for $12 \mathrm{~h}$.

\section{Food deprivation study}

Limacina does not feed in captivity. To study the effect of food deprivation we compared the metabolic rate of freshly-caught individuals with the rates of animals that had been captured on the same date and held in filtered seawater for a period of 1 to $13 \mathrm{~d}$. Although this procedure does not control for the effects of captivity on metabolic rate, it provides the closest possible calculation of the effect of food deprivation 
on metabolism for this species. For food deprivation experiments, 5 individuals of Limacina were kept in a 11 bottle of filtered water. At the conclusion of each experiment, which lasted between 1 to $13 \mathrm{~d}$, they were placed in glass respiration chambers and measured for metabolic rate as described in 'Metabolic rate'. In the food deprivation experiments performed on Limacina, egg masses were spawned in the respiration chambers by the middle of January. Eggs were produced by almost every specimen by January 18, 2008. These egg masses, varying in number, time of deposition, and size, may have influenced the oxygen consumption and ammonia excretion in these experiments. They are reported separately but included in the analysis of food deprivation.

For food deprivation experiments, individual Clione were put in 11 glass jars with filtered seawater in a $-2{ }^{\circ} \mathrm{C}$ refrigerated room immediately after capture and received no food. Those under fed conditions were maintained with 5 randomly selected Limacina. Consumed Limacina were replaced with new prey items each day. These individuals are subsequently referred to as animals which had been held for 1 day of captivity without food. At the end of 1 to $13 \mathrm{~d}$ without food, individuals were placed in glass respiration chambers where their metabolic rate was assessed as described in 'Metabolic rate'. Clione spawned only occasionally in the experimental chambers and those that did were excluded from subsequent analyses.

\section{Phytoplankton}

The spatially and temporally averaged satellite estimate of chlorophyll a ( $\mathrm{chl}$ a) was used as a proxy for food availability for organisms foraging in the larger McMurdo Sea area. Phytoplankton chl a concentrations $\left(\mathrm{mg} \mathrm{m}^{-3}\right)$ were estimated from Sea Viewing Wide Field of View Sensor images of the Ross Sea (9 $\mathrm{km}$ resolution) processed with the standard NASA OC4V4 algorithm (Feldman \& McClain 2009). Geometric means were estimated regionally from $72^{\circ} \mathrm{S}$ to $79^{\circ} \mathrm{S}$ and $162^{\circ} \mathrm{E}$ to $161^{\circ} \mathrm{W}$ and compared among the 1998 to 2009 seasons. Monthly composite images were used in this analysis due to high levels of cloud cover, following methods from Smith et al. (2001) and Seibel \& Dierssen (2003).

\section{Statistical analyses}

Statistics were performed with the STATISTICA software package (StatSoft, version 9). Random effects Analysis of Variance (ANOVA) were conducted to test for differences in metabolic rate or protein content between years. We ran 1-way Analysis of Covariance (ANCOVA) in order to analyze differences in wet mass between years while accounting for the day of the year of collection. Linear regressions were conducted to test the relationship
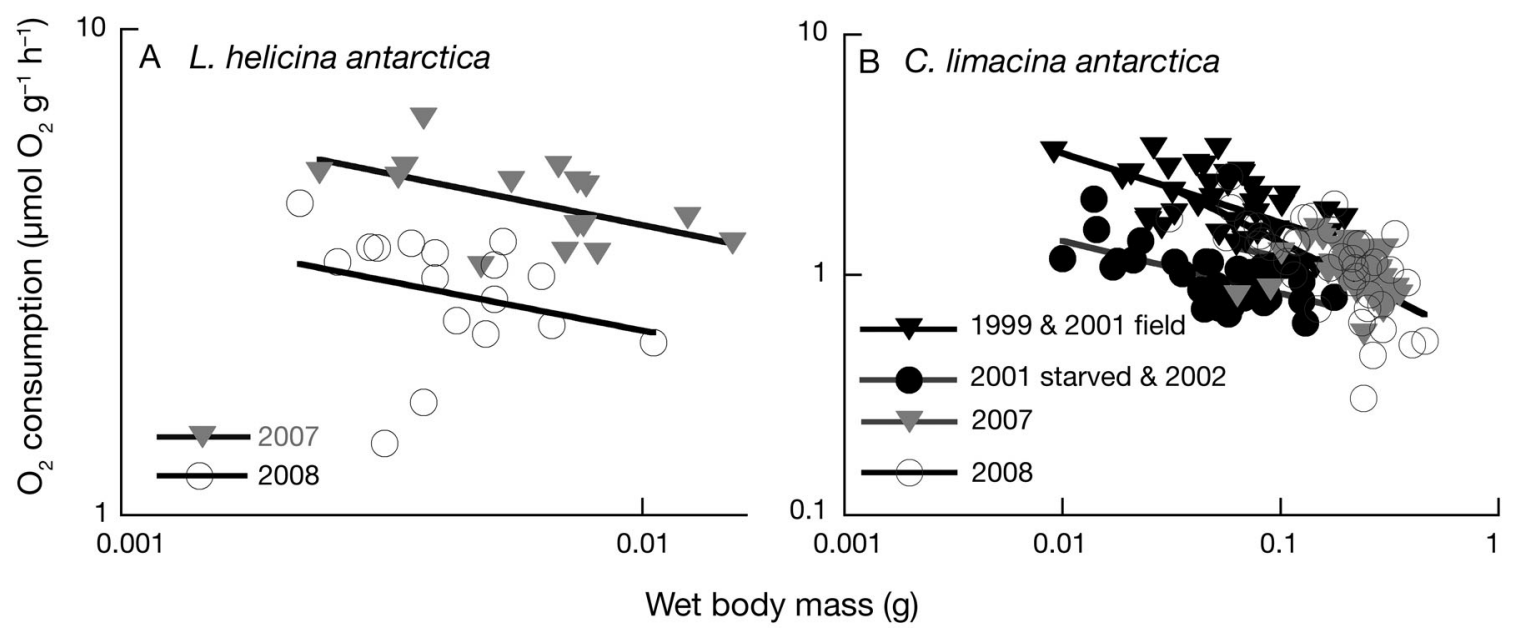

Fig. 2. Limacina helicina antarctica and Clione limacina antarctica. Oxygen consumption rate $\left(\mathrm{Y}, \mu \mathrm{mol} \mathrm{O}_{2} \mathrm{~g}^{-1} \mathrm{~h}^{-1}\right)$ for both species declines with wet body mass $(\mathrm{M})$ according to $\mathrm{Y}=a \mathrm{M}^{b}$. (A) L. helicina antarctica were collected in 2007 $\left(\mathrm{Y}=1.4496 \mathrm{M}^{-0.2181}, \mathrm{r}^{2}=0.29, F_{1,13}=5.43, \mathrm{p}=0.37\right)$ or in $2008\left(0.9182 \mathrm{M}^{-0.2087}, \mathrm{r}^{2}=0.07, F_{1,15}=1.21, \mathrm{p}=0.29\right)$. The scaling coefficient (b) of -0.20 was applied to subsequent analyses. (B) C. limacina antarctica from 2007 and 2008 were maintained in captivity for no more than 3 d prior to measurement. Also shown: results from specimens captured in 1999, 2001 and 2002 (Seibel \& Dierssen 2003). Organisms from that study were assigned as either food deprived or fed depending on their time in the laboratory and the availability of prey in the surrounding water. The combined scaling curve has an equation of $\mathrm{Y}=0.69 \mathrm{M}^{-0.25}$ $\left(\mathrm{r}^{2}=0.25, F_{1,161}=55.21, \mathrm{p}<0.001\right)$. The scaling coefficient $(b)$ of -0.25 was used in further analyses 
between wet mass and oxygen consumption, wet mass and dry mass, and between chl a levels and the oxygen consumption of Limacina. We compared organisms deprived of food for 1 to $3 \mathrm{~d}$ with those deprived for 4 to $13 \mathrm{~d}$ using 2-tailed Student's $t$-tests. Statistics were reported as significant if $\mathrm{p}<0.05$.

\section{RESULTS}

\section{Metabolic rate}

Oxygen consumption was inversely related to wet body mass with an average scaling coefficient $(b)$ of -0.2 in Limacina and -0.25 in Clione (Fig. 2). There was no significant correlation between wet mass and ammonia excretion for either species. A comparison of the oxygen consumption and the year of collection revealed a significant difference between scaled metabolic rates for Limacina with specimens from 1999 having the highest rate followed by 2007, 2001 and 2008 in decreasing order (1-way ANOVA: $F_{3,81}=$ 19.29, p < 0.001, Table 1). Scaled oxygen consumption rates were also significantly different for Clione with the highest rate in 1999, followed by 2001, 2007 , 2008 and with the lowest in 2002 (one-way ANOVA: $F_{4,116}=25.05, \mathrm{p}<0.001$, Table 1).

Whole-animal metabolic responses for organisms living in their natural thermal range generally have a
$\mathrm{Q}_{10}$ value which falls between 2 and 3 . This change in physiological rate allows for an adjustment of physical and enzyme-mediated processes to the changing kinetic energy and equilibrium constants under differing environmental temperatures (Hochachka \& Somero 2002). Antarctic Clione, after being normalized for a wet body mass common to all experimental years (180 mg) and using the scaling coefficient of -0.25 , exhibited a mean oxygen consumption rate at $2^{\circ} \mathrm{C}$ of $1.54 \pm 0.62 \mu \mathrm{mol} \mathrm{g}^{-1} \mathrm{~h}^{-1}$ and $1.13 \pm 0.36$ $\mu \mathrm{mol} \mathrm{g}^{-1} \mathrm{~h}^{-1}$ at $-2^{\circ} \mathrm{C}$ (Table 1). Applying these values yielded a $\mathrm{Q}_{10}$ of 2.15 , much lower than the 3.6 measured in Seibel et al. (2007). Using the same procedure, Limacina was normalized to $5 \mathrm{mg}$ using the scaling coefficient of -0.20 for comparison between temperatures. Their oxygen consumption (mean \pm SD) at $+2{ }^{\circ} \mathrm{C}$ was $3.04 \pm 0.70 \mu \mathrm{mol} \mathrm{g}{ }^{-1} \mathrm{~h}^{-1}$ and $4.55 \pm$ $1.16 \mu \mathrm{mol} \mathrm{g}{ }^{-1} \mathrm{~h}^{-1}$ at $-2^{\circ} \mathrm{C}$, which resulted in a $\mathrm{Q}_{10}$ of 2.75 (Table 1).

\section{Mass and protein content}

The wet mass of captured Limacina increased throughout the collection period in both 2007 and 2008, the only seasons where date of capture was available. Analysis incorporating date of collection showed no difference in wet mass (dependant variable) between years (group: ANCOVA: $F_{1,197}=3.39$,

Table 1. Limacina helicina antarctica and Clione limacina antarctica. Inter-annual variation in pteropod wet mass, oxygen consumption, and scaled oxygen consumption (all means \pm SD) listed by year and treatment. Wet mass (mg) does not take into account variation due to period of collection. $\mathrm{O}_{2}$ consumed and scaled $\mathrm{O}_{2}$ consumed $\left(\mu \mathrm{mol} \mathrm{O}_{2}\right)$ are presented on a mass-specific basis $\left(\mathrm{g}^{-1} \mathrm{~h}^{-1}\right)$. Chlorophyll ( $\mathrm{chl} \mathrm{a}$ ) levels $\left(\mathrm{mg} \mathrm{m}^{-3}\right)$ are the geometric means averaged between December and January. Number of individuals per treatment (n) is the same for wet mass and $\mathrm{O}_{2}$ consumption. Scaling coefficients for C. limacina antarctica are -0.25 normalized to $0.18 \mathrm{~g}$ and -0.20 normalized to $0.005 \mathrm{~g}$ for $L$. helicina antarctica based on the curves in Fig. 2. All individuals were kept at temperature for 20 to $28 \mathrm{~h}$. Starved individuals were kept without food for $>4 \mathrm{~d}$ after capture whereas all other specimens had been in captivity for $\leq 3 \mathrm{~d}$. Starved $2008 \mathrm{~L}$. helicina antarctica averages include individuals that laid eggs during experiments

\begin{tabular}{|c|c|c|c|c|c|c|c|}
\hline Species & Year & Chl a & Treatment & $\mathrm{n}$ & Wet mass & $\mathrm{O}_{2}$ consumption & Scaled $\mathrm{O}_{2}$ consumption \\
\hline $\begin{array}{l}\text { L. helicina } \\
\text { antarctica }\end{array}$ & $\begin{array}{l}1999 \\
2001 \\
2007 \\
2008\end{array}$ & $\begin{array}{l}1.51 \pm 0.83 \\
0.84 \pm 0.47 \\
1.70 \pm 0.37 \\
0.73 \pm 0.24\end{array}$ & $\begin{array}{c}-2^{\circ} \\
-2^{\circ} \\
-2^{\circ} \\
-2^{\circ} \\
-2^{\circ} \text { starved } \\
+2^{\circ}\end{array}$ & $\begin{array}{l}12 \\
22 \\
24 \\
45 \\
18 \\
34\end{array}$ & $\begin{array}{l}4.8 \pm 3.6 \\
4.0 \pm 3.5 \\
7.0 \pm 3.1 \\
4.1 \pm 1.8 \\
5.2 \pm 1.9 \\
7.0 \pm 2.4\end{array}$ & $\begin{array}{l}5.51 \pm 1.53 \\
3.78 \pm 0.73 \\
4.00 \pm 1.13 \\
3.37 \pm 0.89 \\
2.53 \pm 0.83 \\
4.30 \pm 1.11\end{array}$ & $\begin{array}{l}5.25 \pm 1.38 \\
3.49 \pm 0.82 \\
4.16 \pm 1.03 \\
3.21 \pm 0.67 \\
2.58 \pm 0.77 \\
4.51 \pm 1.13\end{array}$ \\
\hline $\begin{array}{l}\text { C. limacina } \\
\text { antarctica }\end{array}$ & $\begin{array}{l}1999 \\
2001 \\
\\
2002 \\
2007 \\
2008\end{array}$ & $\begin{array}{l}1.51 \pm 0.83 \\
0.84 \pm 0.47 \\
2.03 \pm 0.34 \\
1.70 \pm 0.37 \\
0.73 \pm 0.24\end{array}$ & $\begin{array}{c}-2^{\circ} \\
-2^{\circ} \\
-2^{\circ} \text { starved } \\
-2^{\circ} \\
-2^{\circ} \\
-2^{\circ} \\
-2^{\circ} \text { starved } \\
+2^{\circ}\end{array}$ & $\begin{array}{r}10 \\
31 \\
7 \\
30 \\
8 \\
42 \\
42 \\
32\end{array}$ & $\begin{aligned} 90.0 & \pm 52.4 \\
73.7 & \pm 60.0 \\
50.4 & \pm 15.0 \\
68.4 & \pm 40.3 \\
257.2 & \pm 57.9 \\
189.0 & \pm 103.0 \\
168.8 & \pm 105.4 \\
183.7 & \pm 102.2\end{aligned}$ & $\begin{array}{l}1.93 \pm 0.68 \\
2.04 \pm 0.65 \\
0.96 \pm 0.25 \\
1.00 \pm 0.28 \\
1.11 \pm 0.23 \\
1.20 \pm 0.46 \\
0.92 \pm 0.66 \\
1.62 \pm 0.72\end{array}$ & $\begin{array}{r}1.55 \pm 0.45 \\
1.49 \pm 0.37 \\
0.68 \pm 0.14 \\
0.73 \pm 0.14 \\
1.20 \pm 0.23 \\
1.13 \pm 0.36 \\
0.86 \pm 0.62 \\
1.54 \pm 0.62\end{array}$ \\
\hline
\end{tabular}



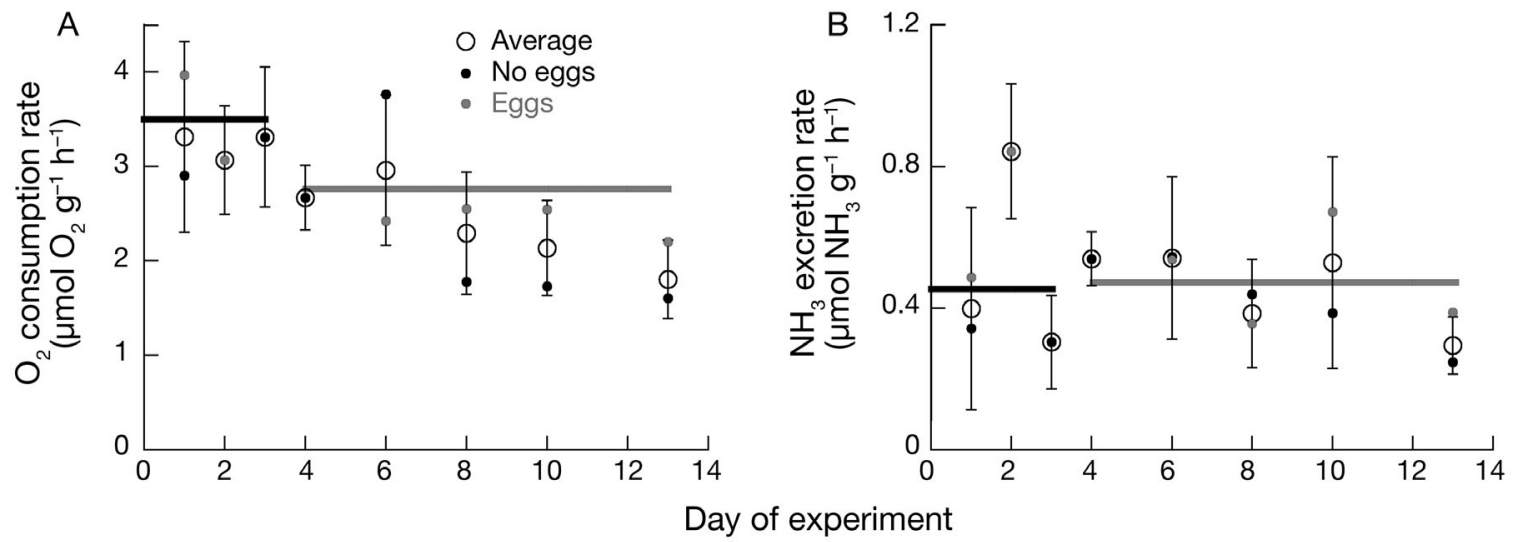

Fig. 3. Limacina helicina antarctica. (A) Average scaled $\mathrm{O}_{2}$ consumption ( $b=-0.20$ normalized to $0.005 \mathrm{~g}$ ) and (B) $\mathrm{NH}_{3}$ excretion of individuals deprived of food. Individuals that laid eggs during the experiment and those which did not are averaged here. Combined values for Days 1 to 3 (regarded as fresh: black bars; $\mathrm{n}=7$ to 26) and for Days 4 to $13 \mathrm{~d}$ (regarded as food deprived: grey bars; $\mathrm{n}=3$ to 5 ) are statistically different for scaled oxygen consumption $\left(t_{63}=3.08, p=0.003\right)$ but not for ammonia excretion $\left(t_{63}=0.26, \mathrm{p}=0.80\right)$

$\mathrm{p}=0.067$ ), but a significant correlation between wet mass and day of the year (continuous predictor: ANCOVA: $\left.F_{1,197}=52.89, \mathrm{p}<0.001\right)$. Specimens collected during comparable time periods (January 26 to February 2) were not statistically different in wet mass between years, with an average weight of 6.67 $\pm 2.26 \mathrm{mg}(t=0.17, \mathrm{df}=157, \mathrm{p}=0.86)$. The equations to convert wet mass (M) to dry mass (DM) and then to ash free dry mass (AFD) in Limacina are: $\mathrm{DM}=$ $0.9692 \ln (\mathrm{M}-0.3758) ;\left(\mathrm{r}^{2}=0.92\right)$ and $\mathrm{AFD}=0.4006 \ln$ $(\mathrm{M}-0.1766) ;\left(\mathrm{r}^{2}=0.65\right)$. These regression equations are similar to those in Seibel et al. (2007).

Collected Clione varied greatly in size, but there was no change of mean wet mass within a season. Analysis incorporating the date of capture revealed that gymnosomes in 2008 were smaller (wet mass, dependant variable) than in 2007 (group: ANCOVA: $F_{1,115}=5.59, \mathrm{p}=0.020$ ) and day of the year had no effect on wet mass (continuous predictor: ANCOVA: $\left.F_{1,115}=0.007, \mathrm{p}=0.94\right)$. Clione captured during the same time period (January 20 to 29) were significantly smaller in 2008, with a wet mass (average \pm $\mathrm{SD})$ of $0.224 \pm 0.063 \mathrm{~g}$ in 2007 and $0.174 \pm 0.095 \mathrm{~g}$ in the following season $(t=4.54$, df $=98, \mathrm{p}<0.001)$. Wet mass was linearly correlated with dry mass for Clione: $\mathrm{DM}=-1.38+0.16 \mathrm{M} ;\left(\mathrm{r}^{2}=0.99, F_{1,4}=478.92\right.$, $\mathrm{p}<0.001)$ as previously reported $(\mathrm{DM}=-0.17+$ 0.13M, Seibel et al. 2007). The regressions were not significantly different from each other.

Protein content was variable in both pteropod species with no strong correlation between percent protein and food deprivation (Limacina, 1-way ANOVA: F6,9 $=0.54, \mathrm{p}=0.76$; Clione, 1-way ANOVA: F8, 27 $=1.39, \mathrm{p}=0.24$ ).

\section{Food deprivation study}

Limacina deprived of food between 4 to $13 \mathrm{~d}$ had a significant decrease in oxygen consumption $(t=3.08$, $\mathrm{df}=63, \mathrm{p}=0.003$ ) with a $20 \%$ lower rate on average than those held for 1 to $3 \mathrm{~d}$. Their nitrogen excretion was variable, but on average there was an initial increase followed by a decline toward pre-starvation levels in only a few days (Fig. 3). Combining these trends, there was a decrease in O:N ratio by about $35 \%$ over the period of food deprivation indicating an increasing reliance on protein catabolism during food deprivation ( $t=2.17$, $\mathrm{df}=63, \mathrm{p}=0.03$, Fig. 4).

Clione deprived of food for 4 to $13 \mathrm{~d}$ responded with a decrease in oxygen consumption rate $(t=4.48$, $\mathrm{df}=79, \mathrm{p}<0.001)$ and ammonia excretion $(t=2.43, \mathrm{df}$ $=79, \mathrm{p}=0.017$ ) over the experimental period as compared with individuals which had fed 1 to $3 \mathrm{~d}$ previously. Average ammonia excretion dropped by 55\% and oxygen consumption by $35 \%$ for organisms kept without food for 4 to $13 \mathrm{~d}$ (Fig. 5). Although there was a reduction in both oxygen consumption and ammonia excretion in response to the lack of food, the decrease was not of the same factor. This results in an average O:N ratio $\sim 50 \%$ higher during food deprivation, indicating a shift in metabolic substrate to lipids $(t=-2.10$, df $=79, \mathrm{p}=0.039$, Fig. 4$)$.

\section{Phytoplankton}

Over the 10 yr reported, chl a concentration varied greatly in McMurdo Sound (Fig. 6). In the year 2008, chl a level was lower $\left(0.73 \mathrm{mg} \mathrm{chl} \mathrm{a} \mathrm{m}^{-3}\right)$ than in 2007 

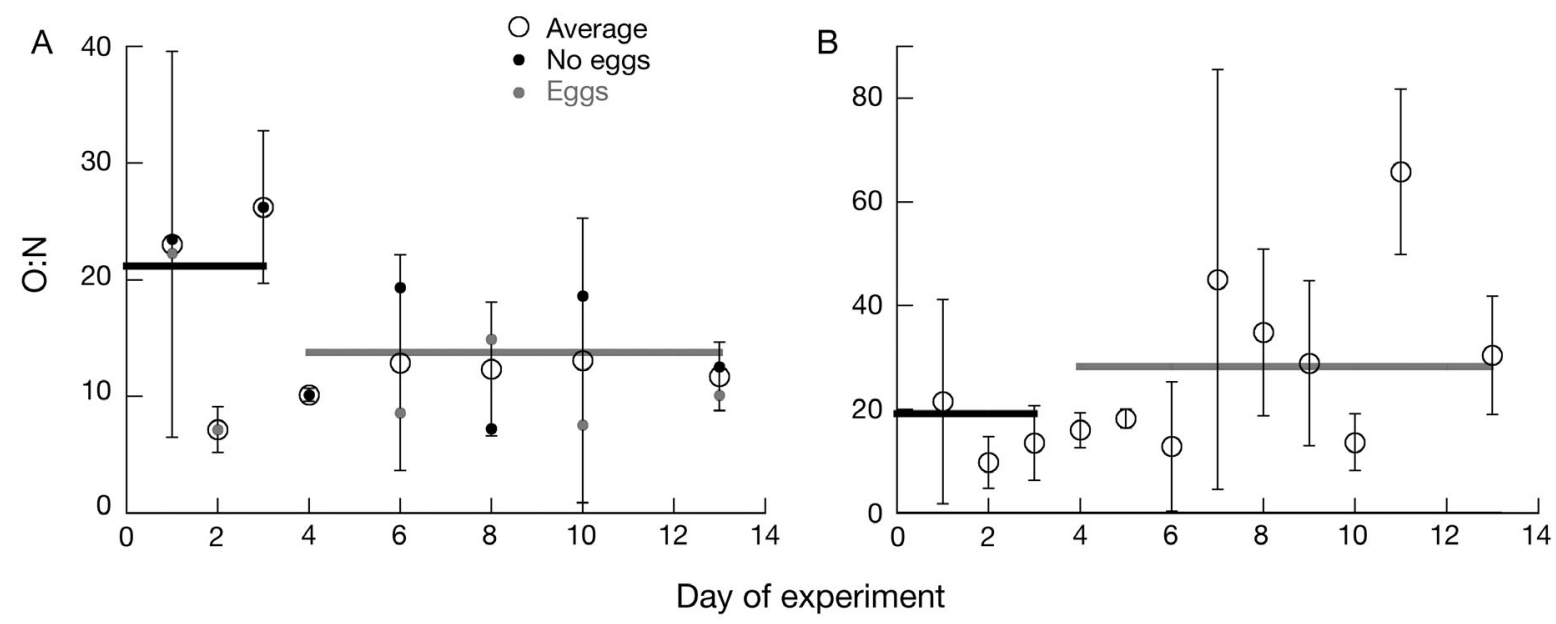

Fig. 4. Limacina helicina antarctica and Clione limacina antarctica. Oxygen to nitrogen ratio (O:N) for fresh (regarded as fed) and food deprived (A) L. helicina antarctica and (B) C. limacina antarctica. In (A) specimens that did or did not lay eggs during the experiment are averaged. Combined values for fresh (Days 1 to 3, regarded as fed: black bars) and food-deprived individuals (Days 4 to 13: grey bars) are statistically different for both species (Limacina: $t_{63}=2.17, \mathrm{p}=0.03, C l i o n e: t_{79}=-2.10, \mathrm{p}=0.04$ )

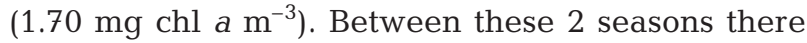
was a $23 \%$ reduction in mean metabolic rate for Limacina. Metabolic rates of Limacina were similarly low in 2001 when chl a levels were also $<1 \mathrm{mg} \mathrm{m}^{-3}$ (Table 1). However, a linear regression assessing the relationship between the scaled average oxygen consumption of the thecosomes and average chl a from 1999 to 2008 revealed no significant correlation $(y=$ $\left.1.59 x+2.09, \mathrm{r}^{2}=0.79, F_{1,3}=3.34, \mathrm{p}=0.21\right)$. No relationships were observed between chl $a$ and the predator Clione.

\section{DISCUSSION}

The available data suggest that Limacina populations respond to reduced food availability in the Ross Sea with a decrease in oxygen consumption. This decline in metabolic rate during years of low productivity was similar to the change in oxygen consumption we observed in the laboratory food deprivation experiments. In the laboratory, 4 to $13 \mathrm{~d}$ of food deprivation significantly reduced the metabolic rate of Limacina as compared to fresh animals deprived of

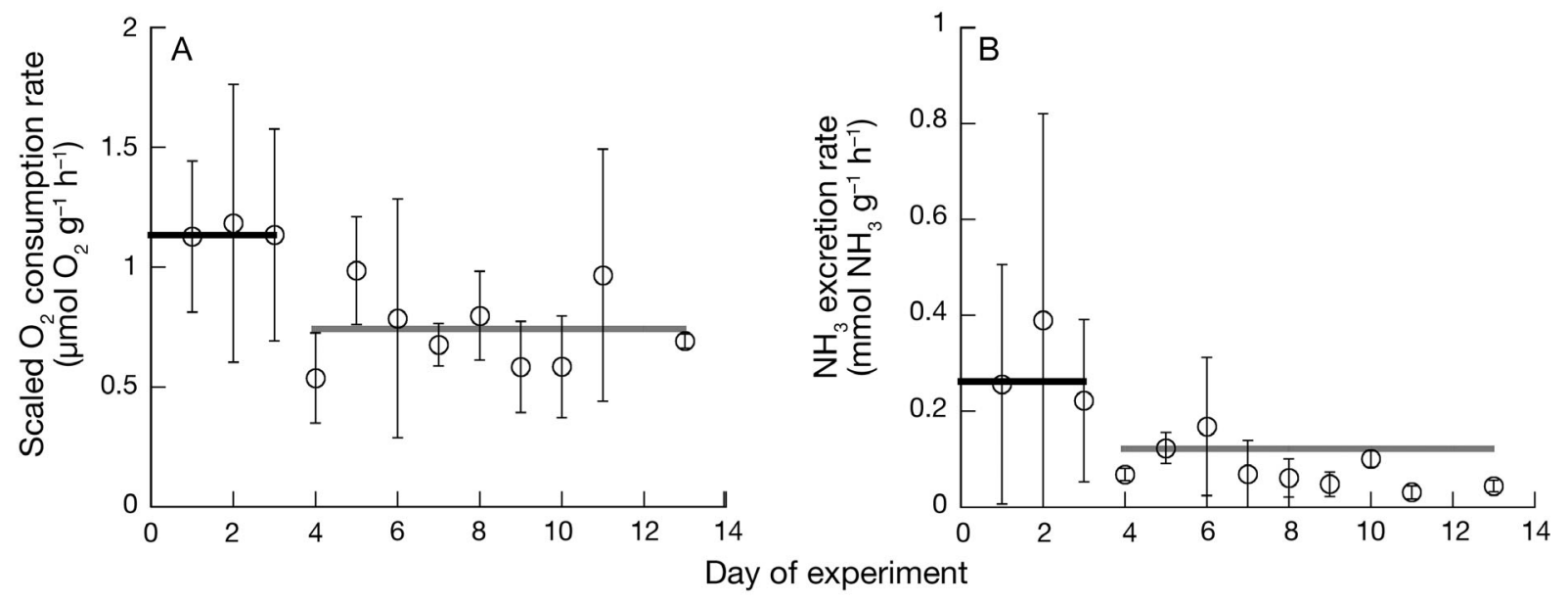

Fig. 5. Clione limacina antarctica. (A) Average scaled oxygen consumption ( $b=-0.25$ normalized to $0.18 \mathrm{~g})$ and (B) average ammonia excretion of fresh and food deprived individuals. Combined values for fresh (Days 1 to 3 , black bars; $\mathrm{n}=4$ to 31 ) and food deprived individuals (Days 4 to 13 , grey bars; $n=3$ to 7 ) are statistically different for both scaled oxygen consumption $\left(t_{79}=4.48, \mathrm{p}<0.001\right)$ and ammonia excretion $\left(t_{79}=2.43, \mathrm{p}=0.02\right)$ 


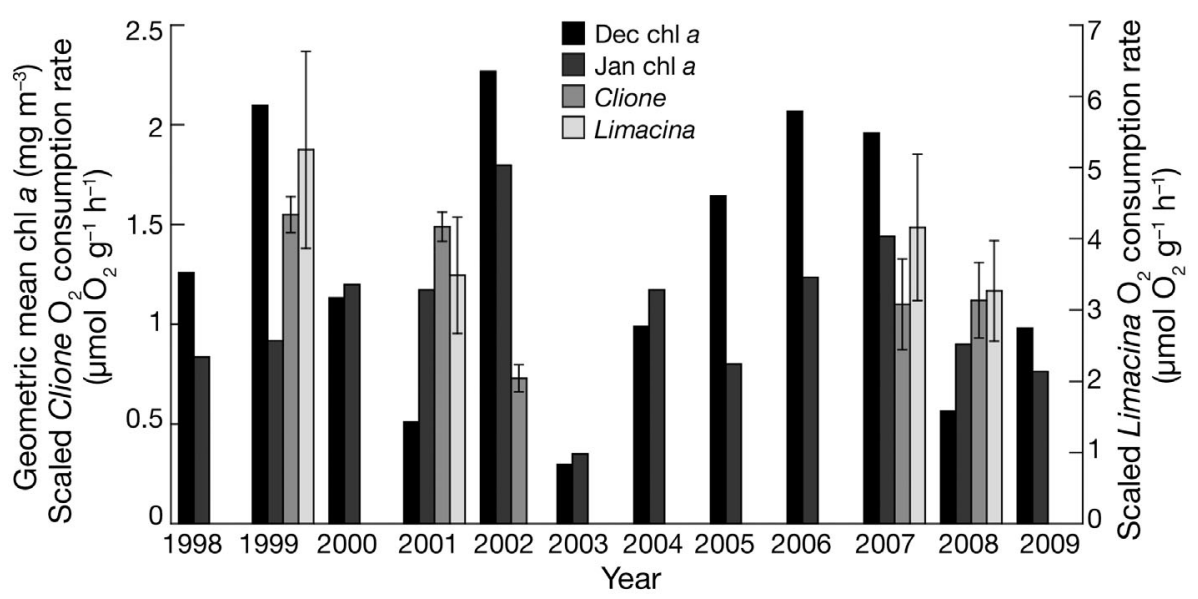

Fig. 6. Geometric means of satellite-derived chlorophyll a from December and January for the region from $72^{\circ} \mathrm{S}$ to $79^{\circ} \mathrm{S}$ and $162^{\circ} \mathrm{E}$ to $161^{\circ} \mathrm{W}$. Oxygen consumption of freshly caught Clione limacina antarctica (Clione) adjusted to the -0.25 coefficient are plotted as mean $\pm 1 \mathrm{SD}$. Oxygen consumption rates (mean $\pm 1 \mathrm{SD}$ ) of freshly caught Limacina helicina antarctica (Limacina) are plotted based on the scaling coefficient of -0.20

food for only 1 to $3 \mathrm{~d}$. The similar response of Clione to food deprivation, and the consistency of organismal size and environmental temperature supports our hypothesis that food availability is responsible for the seasonal differences among the metabolic rates of freshly caught Limacina. Whether this finding is interpreted as the result of an extended specific dynamic action during periods of high food availability, or as metabolic depression during food scarcity, this variation in metabolic rate affects pteropod population production. The laboratory-based food deprivation indicates that the specific dynamic action of both Limacina and Clione is extended in duration and reduced in absolute value when compared with other marine ectotherms (Secor 2009). Like the Antarctic limpet Nacella concinna, whose metabolic rate remains elevated for a number of days after feeding and is 2.3 times higher at its peak (Peck \& Veal 2001) and the Antarctic krill Euphausia superba, whose oxygen consumption is 1.6-fold higher after consuming phytoplankton (Ikeda \& Dixon 1984), food deprived Clione responded to the consumtption of a prey item with a 1.5-fold increase in metabolic rate. Limacina that were deprived of food had a 1.3-fold reduction in oxygen consumption. This lower value in Limacina possibly reflects the variability in the state of freshly caught organisms which were used as a control, an experimental design that was unavoidable because thecosomes do not feed in captivity.

Periods of reduced metabolism are achieved through lower energy demand - generally by mini- mizing energetically costly behaviors and processes (e.g. locomotion and growth), while other processes, such as reproduction, may be delayed enabling survival until food becomes plentiful (Wang et al. 2006). Food deprivation has been implicated in reduced recruitment and juvenile resiliency in Antarctic krill (Daly 2004, Loeb et al. 2009) and caused delayed reproduction in a subpolar pteropod, Limacina retroversa (Böer et al. 2006, Bernard \& Froneman 2009). Based on what is known of the life cycle of Limacina, reproductive success of this species may depend on the food availability in multiple seasons. This hypothesis is supported by the local extinction of Limacina in 2002, following a season with low primary productivity due to the presence of iceberg B-15 (Arrigo et al. 2002, Seibel \& Dierssen 2003). Available data suggest that Limacina overwinters as a veliger, metamorphoses in spring, and increases in mass until spawning in late summer to early fall (Gannefors et al. 2005, Hunt et al. 2008). This hypothetical life cycle is consistent with the size distribution in our samples, and ubiquitous egg-laying in mid January 2008. Our study suggests that poor nourishment may be a mechanism driving reduced recruitment for Limacina.

Smaller reserves of energy for over wintering, vulnerability to predators due to impaired locomotion, and delayed or failed reproduction are all likely consequences of chronic metabolic suppression that may affect populations in subsequent years. The usefulness of metabolic suppression as a response to stress is dependent upon the duration of the stressor and the adequacy of energy reserves. Polar pteropods, both thecosomatous and gymnosomatous, possess large stores of specialized lipids that sustain them in an environment characterized by extreme spatial and temporal food patchiness (Kattner et al. 1998, Phleger et al. 1998, 2001). The northern congener of Limacina, L. helicina, is documented to rely heavily on lipid stores during periods of food deprivation (Gannefors et al. 2005, Böer et al. 2005, 2006). Typically, polar organisms rely more heavily on protein catabolism when food is plentiful and then, when food becomes scarce, they switch to the use of lipid stores (Brockington \& Clarke 2001). In the present 
study the ratio of oxygen consumed to nitrogen excreted (O:N) in Limacina decreased, indicating a greater reliance on protein catabolism after 4 to $13 \mathrm{~d}$ of food deprivation. This difference may be a product of our inability to directly control the feeding status of Limacina, as we could not quantify the amount of food ingested prior to capture in 2008, a year where chl a levels were low, which potentially resulted in the observed variability in ammonia excretion. Alternately, these results may reflect real differences in energetic strategy between the northern and southern populations which, although not yet reflected in the confused taxonomy of pteropods, have been shown to be physiologically and genetically distinct (Seibel et al. 2007, Rosenthal et al. 2009, Hunt et al. 2010).

Metabolic suppression and local extinction may have wide ranging effects on higher trophic levels as Limacina is an important food source for a number of invertebrate and vertebrate predators (Lalli \& Gilmer 1989, Foster \& Montgomery 1993, Hunt et al. 2008). The effects are readily apparent in the monophagous predator, Clione. This gymnosomatous pteropod feeds exclusively on Limacina and, in laboratory experiments, consumes $\sim 0.2 \mathrm{mg}$ dry mass per day (Dymowska et al. in press). In 2002, Limacina was absent for the first time on record and the metabolic rate of freshly caught Clione was reduced by $\sim 50 \%$ that season (Seibel \& Dierssen 2003). Our experiments indicate that Clione elevates metabolism for about $3 \mathrm{~d}$ following feeding, after which both oxygen consumption and ammonia excretion are reduced. This response to food limitation is similar to that expressed by the Arctic congener C. limacina (Conover \& Lalli 1974). C. limacina substantially suppresses metabolism during periods of food deprivation, using up lipid and protein simultaneously. This results in overall body shrinkage and a documented survival during food deprivation for 356 d (Böer et al. 2006, 2007). During 2002, when Limacina was absent, Clione exhibited the lowest mean scaled oxygen consumption of the $5 \mathrm{yr}$ of available data. The next lowest year was 2008, when Limacina showed lowest metabolic rates. The highest metabolic rates for both species were in 1999. This apparent relationship between chl $a$ and oxygen consumption for both predator and prey suggests that food availability may affect the quality, not just quantity, of Limacina. In years with limiting primary productivity, or less nutritious food sources, Limacina may have had reduced lipid stores and lower caloric value for the predator Clione, as well as other predators.
Metabolic suppression has been successful in this environment where distinct seasonality and short term climate oscillations such as the Pacific Decadal Oscillation, the El Niño-Southern Oscillation, the semi-annual oscillation and the Antarctic Oscillation Index modify the amount of food available (Ainley et al. 2005, Trathan et al. 2007). The concern is that anthropogenic climate change may impact both the quantity and quality of phytoplankton available in surface waters (Dierssen 2010). Changes in temperature and ice cover (Parkinson 2004, Montes-Hugo et al. 2008, Stammerjohn et al. 2008), ffect phytoplankton populations by modifying stratification, iron availability, irradiance and nutrient levels. The densities and species distribution of phytoplankton are largely controlled by these physical factors (Arrigo et al. 1998, Clarke \& Gaston 2006), and subsequently drive food availability and quality for zooplankton. Ocean acidification may also alter productivity and phytoplankton species dynamics, favoring large diatoms over Phaeocystis antarctica (Tortell et al. 2008).

Our experiments provide information about the response of pteropods to changes in food level, implicating food deprivation as the cause of low oxygen consumption in Limacina during years when chl $a$ is reduced in the Ross Sea region. Our results support the conclusion that Limacina was missing during 2001 as a result of $2 \mathrm{yr}$ of low phytoplankton availability, in part due to the blockage of McMurdo Sound by iceberg B-15 (Seibel \& Dierssen 2003). The local extinction of this species and the metabolic response of its predator Clione, suggest that climateinduced changes in food availability and composition could have ecosystem-wide impacts with important implications for biogeochemical cycles.

Acknowledgements. We thank P. Walsh, C. Oviatt, K. Wishner, C. Thornber, and R. Bullock for their helpful mentorship, discussions, and comments on the manuscript. We are thankful for the assistance of P. Walsh, V. Fabry, T. Hall, D. Faber, L. Williams, L. Huber-Greene, R. Gonzales, G. Hofmann, J. Tollison, and B. Greene in the field and laboratory. We thank Raytheon Polar Services, the National Science Foundation - Office of Polar Programs and the staff at McMurdo station for funding and field support. This research was supported by NSF grant ANT-0538479 to B.A.S and V. Fabry and additionally by the University of Rhode Island and the Rhode Island EPSCoR Fellowship to A.E.M.

\section{LITERATURE CITED}

Accornero A, Manno C, Esposito F, Gambi MC (2003) The vertical flux of particulate matter in the polynya of Terra Nova Bay. Part II: Biological components. Antarct Sci 15: 175-188 
Ainley DG, Clarke ED, Arrigo K, Fraser WR, Kato A, Barton KJ, Wilson PR (2005) Decadal-scale changes in the climate and biota of the Pacific sector of the Southern Ocean, 1950s to the 1990s. Antarct Sci 17:171-182

> Arrigo KR, Weiss AM, Smith WO Jr (1998) Physical forcing of phytoplankton dynamics in the southwestern Ross Sea. J Geophys Res 103:1007-1021 doi:10.1029/97JC 02326

Arrigo KR, Robinson DH, Worthen DL, Dunbar RB, DiTullio GR, VanWoert M, Lizotte MP (1999) Phytoplankton community structure and the drawdown of nutrients and $\mathrm{CO}_{2}$ in the southern ocean. Science 283:365-367

Arrigo KR, van Dijken GL, Ainley DG, Fahnestock M, Markus T (2002) Ecological impact of a large Antarctic iceberg. Geophys Res Lett 29:8.1-8.4 doi:10.1029/2001 GL014160

Bernard KS, Froneman PW (2009) The sub-Antarctic euthecosome pteropod, Limacina retroversa: distribution patterns and trophic role. Deep-Sea Res I 56:582-598

> Böer M, Gannefors C, Kattner G, Graeve M, Hop H, FalkPetersen S (2005) The Arctic pteropod Clione limacina: seasonal lipid dynamics and life-strategy. Mar Biol 147: 707-717

Böer M, Graeve M, Kattner G (2006) Impact of feeding and starvation on the lipid metabolism of the Arctic pteropod Clione limacina. J Exp Mar Biol Ecol 328:98-112

Böer M, Graeve M, Kattner G (2007) Exceptional long-term starvation ability and sites of lipid storage of the Arctic pteropod Clione limacina. Polar Biol 30:571-580

Brockington S, Clarke A (2001) The relative influence of temperature and food on the metabolism of a marine invertebrate. J Exp Mar Biol Ecol 258:87-99

Bryan PJ, Yoshida WY, McClintock JB, Baker BJ (1995) Ecological role for pteroenone, a novel antifeedant from the conspicuous Antarctic pteropod Clione antarctica (Gymnosomata: Gastropoda). Mar Biol 122:271-277

Childress JJ, Seibel BA (1998) Life at stable low oxygen levels: adaptations of animals to oceanic oxygen minimum layers. J Exp Biol 201:1223-1232

Clarke A (1988) Seasonality in the antarctic marine environment. Comp Biochem Physiol B 90:461-473

Clarke A, Gaston KJ (2006) Climate, energy and diversity. Proc Biol Sci 273:2257-2266

Collier R, Dymond J, Honjo S, Manganini S, Francois R, Dunbar R (2000) The vertical flux of biogenic and lithogenic material in the Ross sea: moored sediment trap observations 1996-1998. Deep-Sea Res II 47:3491-3520

> Conover RJ, Lalli CM (1974) Feeding and growth in Clione limacina (Phipps), a pteropod mollusc II. Assimilation, metabolism, and growth efficiency. J Exp Mar Biol Ecol 16:131-154

> Daly KL (2004) Overwintering growth and development of larval Euphausia superba: an interannual comparison under varying environmental conditions west of the Antarctic Peninsula. Deep-Sea Res II 51:2139-2168

> Dierssen HM (2010) Perspectives on empirical approaches for ocean color remote sensing of chlorophyll in a changing climate. Proc Natl Acad Sci USA 107:17073-17078

Dymowska AK, Manfredi T, Rosenthal JC, Seibel BA (in press) High performance muscle in a cold Antarctic snail: muscle and mitochondrial morphometrics in the pteropod, Clione antarctica (Gymnosomata: Gastropoda). J Exp Biol

> Elliott DT, Tang KW, Shields AR (2009) Mesozooplankton beneath the summer sea ice in McMurdo Sound, Antarc- tica: abundance, species composition, and DMSP content. Polar Biol 32:113-122

Fabry VJ, Seibel BA, Feely RA, Orr JC (2008) Impacts of ocean acidification on marine fauna and ecosystem processes. ICES J Mar Sci 65:414-432

Feldman GC, McClain CR (2009) Ocean Color Web. Accessed 2 Feb 2009 http://oceancolor.gsfc.nasa.gov

- Foster BA, Montgomery JC (1993) Planktivory in benthic nototheniid fish in McMurdo Sound, Antarctica. Environ Biol Fishes 36:313-318

Gannefors C, Böer M, Kattner G, Graeve M and others (2005) The Arctic sea butterfly Limacina helicina: lipids and life strategy. Mar Biol 147:169-177

Gilmer RW, Harbison GR (1986) Morphology and field behavior of pteropod molluscs: feeding methods in the families Cavoliniidae, Limacinidae and Peraclididae (Gastropoda: Thecosomata). Mar Biol 91:47-57

Gilmer RW, Harbison GR (1991) Diet of Limacina helicina (Gastropoda: Thecosomata) in Arctic waters in midsummer. Mar Ecol Prog Ser 77:125-134

Gilmer RW, Lalli CM (1990) Bipolar variation in Clione, a gymnosomatous pteropod. Am Malacol Bull 81:67-75

Hochachka PW, Somero GN (2002) Biochemical adaptation: mechanism and process in physiological evolution. Oxford University Press, New York, NY

> Honjo S (2004) Particle export and the biological pump in the Southern Ocean. Antarct Sci 16:501-516

> Honjo S, Francois R, Manganini S, Dymond J, Collier R (2000) Particle fluxes to the interior of the Southern Ocean in the Western Pacific sector along 170 W. DeepSea Res II 47:3521-3548

> Hopkins TL (1987) Midwater food web in McMurdo Sound, Ross Sea, Antarctica. Mar Biol 96:93-106

Hunt BPV, Pakhomov EA, Hosie GW, Siegel V, Ward P, Bernard K (2008) Pteropods in Southern Ocean ecosystems. Prog Oceanogr 78:193-221

Hunt B, Strugnell J, Bednarsek N, Linse K and others (2010) Poles apart: the 'bipolar' pteropod species Limacina helicina is genetically distinct between the Arctic and Antarctic Oceans. PLoS ONE 5:e9835

> Ikeda T, Dixon P (1984) The influence of feeding on the metabolic activity of antarctic krill (Euphausia superba Dana). Polar Biol 3:1-9

Ivancic I, Degobbis D (1984) An optimal manual procedure for ammonia analysis in natural waters by the indophenol blue method. Water Res 18:1143-1147

Kattner G, Hagen W, Graeve M, Albers C (1998) Exceptional lipids and fatty acids in the pteropod Clione limacina (Gastropoda) from both polar oceans. Mar Chem 61: 219-228

Lalli CM, Gilmer RW (1989) Pelagic snails: the biology of holoplanktonic gastropod mollusks. Stanford University Press, Standford, CA

Loeb VJ, Hofmann EE, Klinck JM, Holm-Hansen O, White WB (2009) ENSO and variability of the Antarctic Peninsula pelagic marine ecosystem. Antarct Sci 21:135-148

Manno C, Tirelli V, Accornero A, Fonda Umani S (2010) Importance of the contribution of Limacina helicina faecal pellets to the carbon pump in Terra Nova Bay (Antarctica). J Plankton Res 32:145-152

> Marsh AG, Manahan DT (1999) A method for accurate measurements of the respiration rates of marine invertebrate embryos and larvae. Mar Ecol Prog Ser 184:1-10

Moline MA, Karnovsky NJ, Brown Z, Divoky GJ and others (2008) High latitude changes in ice dynamics and their 
impact on polar marine ecosystems. Ann N Y Acad Sci 1134:267-319

Montes-Hugo MA, Vernet M, Martinson D, Smith R, Iannuzzi R (2008) Variability on phytoplankton size structure in the western Antarctic Peninsula (1997-2006). Deep-Sea Res II 55:2106-2117

> Orr JC, Fabry VJ, Aumont O, Bopp L and others (2005) Anthropogenic ocean acidification over the twenty-first century and its impact on calcifying organisms. Nature 437:681-686

Pakhomov EA, Froneman PW, Wassmann P, Ratkova T, Arashkevich E (2002) Contribution of algal sinking and zooplankton grazing to downward flux in the Lazarev Sea (Southern Ocean) during the onset of phytoplankton bloom: a lagrangian study. Mar Ecol Prog Ser 233:73-88

Parkinson CL (2004) Southern Ocean sea ice and its wider linkages: insights revealed from models and observations. Antarct Sci 16:387-400

Peck LS, Veal R (2001) Feeding, metabolism and growth in the antarctic limpet, Nacella concinna (Strebel 1908). Mar Biol 138:553-560

Phleger CF, Nichols PD, Virtue P (1998) Lipids and trophodynamics of Antarctic zooplankton. Comp Biochem Physiol B 120:311-323

Phleger CF, Nelson MM, Mooney BD, Nichols PD (2001) Interannual variations in the lipids of the Antarctic pteropods Clione limacina and Clio pyramidata. Comp Biochem Physiol B 128:553-564

Rosenthal JJ, Seibel BA, Dymowska A, Bezanilla F (2009) Trade-off between aerobic capacity and locomotor capability in an Antarctic pteropod. Proc Natl Acad Sci USA 106:6192-6196

Ross RM, Quetin LB, Baker KS, Vernet M, Smith RC (2000) Growth limitation in young Euphausia superba under field conditions. Limnol Oceanogr 45:31-43

Ross RM, Quetin LB, Martinson DG, Iannuzzi RA, Stammerjohn SE, Smith RC (2008) Palmer LTER: patterns of distri-

Editorial responsibility: James McClintock, Birmingham, Alabama, USA bution of 5 dominant zooplankton species in the epipelagic zone west of the Antarctic Peninsula, 1993-2004. Deep-Sea Res II 55:2086-2105

Sarmiento JL, Hughes TMC, Stouffer RJ, Manabe S (1998) Simulated response of the ocean carbon cycle to anthropogenic climate warming. Nature 393:245-249

Secor SM (2009) Specific dynamic action: a review of the postprandial metabolic response. J Comp Physiol B 179: $1-56$

Seibel BA, Dierssen HM (2003) Cascading trophic impacts of reduced biomass in the Ross Sea, Antarctica: just the tip of the iceberg? Biol Bull 205:93-97

Seibel BA, Fabry VJ (2003) Marine biotic response to elevated carbon dioxide. Adv App Biodiv Sci 4:59-67

Seibel BA, Dymowska A, Rosenthal J (2007) Metabolic temperature compensation and co-evolution of locomotory performance in pteropod molluscs. Integr Comp Biol 47 : 880-891

Smith RC, Baker KS, Dierssen HM, Stammerjohn SE, Vernet M (2001) Variability of primary production in an Antarctic marine ecosystem as estimated using a multi-scale sampling strategy. Am Zool 41:40-56

Stammerjohn SE, Martinson DG, Smith RC, Yuan X, Rind D (2008) Trends in Antarctic annual sea ice retreat and advance and their relation to El Niño-Southern Oscillation and Southern Annular Mode variability. J Geophys Res 113:C03S90 doi: 10.1029/2007JC004269

- Tortell PD, Payne CD, Li Y, Trimborn S and others (2008) $\mathrm{CO}_{2}$ sensitivity of Southern Ocean phytoplankton. Geophys Res Lett 35:L04605 doi: 10.1029/2007GL032583

Trathan PN, Forcada J, Murphy EJ (2007) Environmental forcing and Southern Ocean marine predator populations: effects of climate change and variability. Philos Trans R Soc Lond B Biol Sci 362:2351-2365

> Wang T, Hung CCY, Randall DJ (2006) The comparative physiology of food deprivation: from feast to famine. Annu Rev Physiol 68:223-251

Submitted: February 2, 2011; Accepted: August 23, 2011 Proofs received from author(s): October 28, 2011 